\title{
Mapping Economic Feasibility of Managed Aquifer Recharge
}

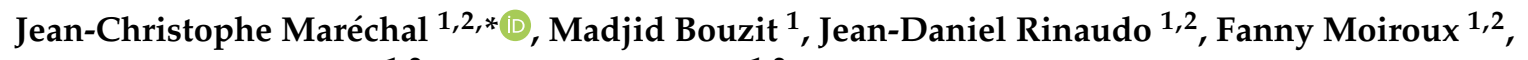 \\ Jean-François Desprats ${ }^{1,2}$ and Yvan Caballero ${ }^{1,2}$ \\ 1 Bureau de Recherches Géologiques et Minières (BRGM), 34000 Montpellier, France; \\ m.bouzit@brgm.fr (M.B.); jd.rinaudo@brgm.fr (J.-D.R.); fanny.moiroux@outlook.fr (F.M.); \\ jf.desprats@brgm.fr (J.-F.D.); y.caballero@brgm.fr (Y.C.) \\ 2 University of Montpellier, 34000 Montpellier, France \\ * Correspondence: jc.marechal@brgm.fr; Tel.: +33-467-157-965
}

Received: 17 November 2019; Accepted: 18 February 2020; Published: 2 March 2020

\begin{abstract}
Managed aquifer recharge (MAR) constitutes a potential and promising solution to deal with several water management issues: water shortage, water level depletion, groundwater pollution, and saline water intrusion. Among others, the proper siting and cost evaluation of such a solution constitutes sources of uncertainty for the implementation of MAR schemes. In this study, we proposed a methodology for the assessment of the levelised cost of recharged water through an infiltration basin, including investment and operating costs. The method was implemented in a GIS-tool in order to build maps of levelised costs at the aquifer scale. The sensitivity analysis allows for the identification of the main natural characteristics (water quality and availability, etc.), technical (system life duration, recharge volume objective, etc.), and economic parameters (energy price, discount rate, etc.) that dominate the final cost estimate. The method was applied to a specific case study on an alluvial aquifer in Southern France. This new information on the economic feasibility of MAR scheme should be incorporated with more classical GIS-MCDA (relying on soil characteristics, aquifer storage capacity, land use, etc.) in order to properly site the system. Further information on financial and economic feedback from MAR implementation and research on the fate of recharged water are needed for a better benefits evaluation of this solution.
\end{abstract}

Keywords: infiltration basin; cost function; suitability map; groundwater; MAR; GIS-MCDA

\section{Introduction}

Groundwater is the world's largest freshwater resource. It provides an increasing quantity of water for irrigated agriculture and hence for global food security. If groundwater abstraction exceeds the natural recharge for a long period of time, intensive use and induced groundwater depletion occur. Depletion is widespread in large groundwater systems of the world [1]. Excessive extraction for irrigation where groundwater is slowly renewed is the main cause of the depletion, and climate change should exacerbate the problem in some regions where natural recharge is expected to decrease (the Mediterranean area for example). The effects of groundwater depletion are complex and dependent on the aquifer, and include (i) lowering of water tables leading to increased cost of pumping or drying up of wells [2]; (ii) reduced groundwater baseflow to streams, springs, and wetlands affecting ecosystems [2]; and (iii) land subsidence potentially damaging buildings and infrastructure [2]. Lowered water tables can lead to salinization by saltwater intrusion in coastal regions. Similarly, groundwater depletion can promote the spread of other types of pollution [2].

Managed aquifer recharge (MAR) constitutes very promising solutions for dealing with water shortage, water level depletion, groundwater pollution, and saline water intrusion [3]. It consists 
of infiltrating water abstracted from surface water resources (rivers, streams, lakes, etc.) through infiltration basins (indirect recharge) or injection wells (direct recharge [4]) in order to increase the natural groundwater recharge.

It is important to properly locate MAR systems according to the infiltration characteristics of the soil, the aquifer capacity to store water, the water resource location, and land use constraints. The site suitability assessment for MAR can be achieved by combining multi-criteria decision analysis (MCDA) for solving spatial problems with geographical information systems (GIS). For that purpose, many studies have been published in the literature describing methods for mapping the technical suitability of MAR solutions, most of them using GIS tools [5-7]. They combined the spatial analysis capacity of GIS with MCDA methodology that guides the decision making process-the resulting approach is called GIS-MCDA and has been recently implemented on web tools [8].

Despite many benefits and demonstrated advantages of the MAR, the growth of this solution has been much lower than expected due to the lack of a sound economic feasibility analysis. The performance and cost-benefit analysis of MAR scheme are key factors for the sustainability of this solution [9]. The costs of MAR schemes are influenced by a wide variety of hydrogeological, socio-economic, and legal and institutional factors [10].

A short review of GIS-MCDA for suitability mapping of MAR schemes shows that, except for a few studies [11], the cost is rarely included in such an analysis, maybe because of a lack of feedback on costs and financial data on MAR devices [10]. Despite the fact that several environmental variables (such as soil infiltration rate [12]) constitute a surrogate for economic evaluation, a specific economic analysis of MAR can bring about substantial information into a GIS-MCDA for MAR location [11].

In this study, we proposed to elaborate the cost function of recharge devices, taking into account capital and operating costs in order to compute the levelised cost of MAR. This cost function was spatially distributed in order to build a map of levelised cost in the study area. This method allowed for the identification of the part of a territory where the cost of MAR is expected to be lower compared with other regions, subject to the hydrogeological characteristics that affect aquifer storage capacity, the ability to recover water for high valued uses, and the environmental impacts of imposed changes to groundwater conditions.

\section{Methodology}

\subsection{MAR Project Design}

One MAR scheme can be divided into several engineering components (Figure 1): water abstraction system from the surface stream, water transfer pipe, pretreatment system, infiltration basin, and surface and groundwater monitoring.

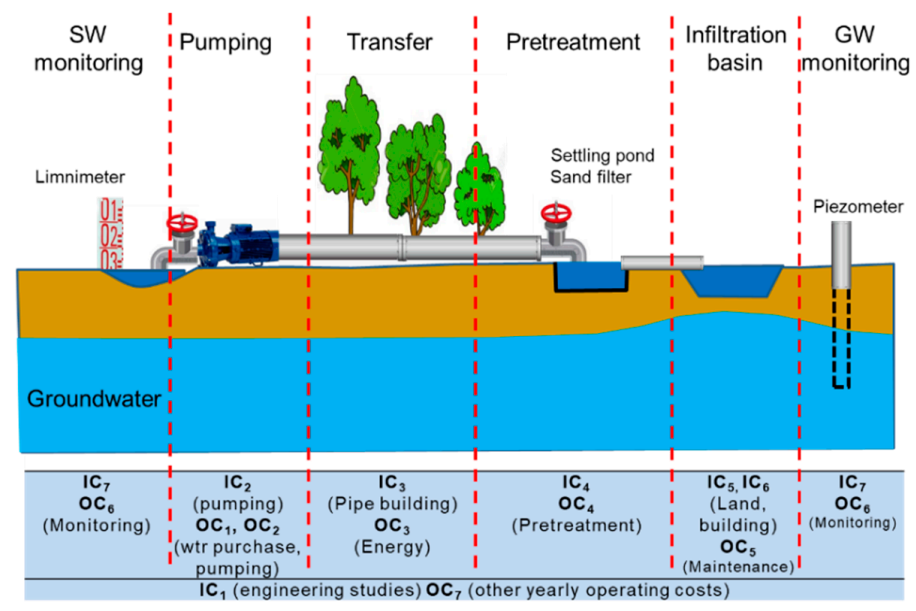

Figure 1. Main engineering components of a managed aquifer recharge (MAR) scheme with infiltration basin and associated investment (IC) and operating costs (OC). 
Several parameters or natural characteristics constitute a set of values that characterize the MAR scheme project (Table 1). The size of an infiltration basin depends on the natural characteristics of the soil and the target water volume $(Q)$ to be recharged. The soil infiltration rate $(i)$ is a key parameter as the surface area $\left(S_{B}\right)$ of the required infiltration basin is inversely proportional to this soil characteristic. The basin size is also linearly proportional to the target volume of recharge. The rate and the yearly duration of infiltration $(N)$ are dependent on the water availability into the surface reservoir and provide the instantaneous flow rate $(q)$ that are taken into account for calculating the diameter $d_{i}$ of the pipes necessary for transferring the water from the abstraction place to the infiltration basin. Distance $D$ and elevation difference $Z$ between the surface water resource and the infiltration basin constitute the main characteristics to design the transfer infrastructure. The main parameters of such a project are listed in Table 1. These parameters are used for estimating the cost of the MAR scheme. Other site-specific parameters may also be incorporated in the analysis.

Table 1. Main parameters of an MAR scheme with infiltration basin project design.

\begin{tabular}{|c|c|c|c|c|}
\hline Process & Parameter & Parameter & Unit & Comment \\
\hline Water monitoring & $\begin{array}{l}\text { No specific } \\
\text { parameter }\end{array}$ & - & - & - \\
\hline \multirow{3}{*}{ Water abstraction } & Recharge rate & $Q$ & $\mathrm{~m}^{3} /$ year & $\begin{array}{l}\text { Annual recharge rate } \\
\text { objective for the MAR }\end{array}$ \\
\hline & $\begin{array}{c}\text { Recharge duration } \\
\text { per year }\end{array}$ & $N$ & d/year & $\begin{array}{l}\text { Yearly duration of the } \\
\text { period during which water } \\
\text { can be abstracted }\end{array}$ \\
\hline & Flow rate & $q=\frac{Q}{N}$ & $\begin{array}{c}\mathrm{m}^{3} / \text { day } \\
\mathrm{m}^{3} / \mathrm{h}\end{array}$ & $\begin{array}{l}\text { Daily/hourly flow rate for } \\
\text { pipe diameter sizing }\end{array}$ \\
\hline \multirow{4}{*}{ Water transfer } & Distance & $D$ & $\mathrm{~m}$ & \multirow{2}{*}{$\begin{array}{l}\text { Between abstraction and } \\
\text { recharge points }\end{array}$} \\
\hline & Altitude difference & $Z$ & $\mathrm{~m}$ & \\
\hline & Head losses & $\begin{array}{c}H= \\
-Z+0.011 D\end{array}$ & $\mathrm{~m}$ & $\begin{array}{l}\text { Assumption: linear head } \\
\text { losses }=0.01 \mathrm{~m} / \mathrm{m} \text { of pipe }\end{array}$ \\
\hline & Pipe diameter & $d_{i}=22.9 q^{0.4}$ & $\mathrm{~mm}$ & Hydraulic law \\
\hline Water pretreatment & $\begin{array}{l}\text { No specific } \\
\text { parameter }\end{array}$ & - & - & - \\
\hline \multirow{4}{*}{ Water infiltration } & Soil infiltration rate & $i$ & m/day & From in situ measurements \\
\hline & $\begin{array}{l}\text { Infiltration basin } \\
\text { surface area }\end{array}$ & $S_{B}=\frac{q}{i}$ & $\mathrm{~m}^{2}$ & \\
\hline & $\begin{array}{l}\text { Scheme surface } \\
\text { area }\end{array}$ & $S_{S}=1,1 S$ & $\mathrm{~m}^{2}$ & $\begin{array}{l}\text { Assumption: } 10 \% \text { extra } \\
\text { land necessary for } \\
\text { neighbouring }\end{array}$ \\
\hline & Basin depth & $d$ & $\mathrm{~m}$ & $d$ between 1 and $3 \mathrm{~m}$ \\
\hline
\end{tabular}

\subsection{Economical Approach-Cost Function}

On the basis of the parameters/characteristics from Table 1, a cost function was built in order to compute the capital and operating costs of a MAR scheme using infiltration basins. These costs are described below according to the engineering component to which they are associated (Figure 1) and summarized in Table 2.

\subsubsection{Investment Costs}

The investment costs of a MAR project such as an infiltration basin cover seven main expenditure items:

- $\quad$ Cost of preliminary studies $\left(I C_{1}\right)$ : All preliminary characterization studies of the recharge site

(e.g., geological and hydrogeological characterization, technico-economic study, impact study, 
and preparation of the authorization file). In general, in "water" projects, this cost represents between $5 \%$ and $20 \%$ of the total investment cost depending on the size and complexity of the recharge project.

- Water abstraction cost $\left(I C_{2}\right)$ : cost of civil engineering works for the pumping of water out of the river/canal, as well as pumping equipment (in the case where gravity supply is not possible).

- Water transfer cost $\left(I C_{3}\right)$ : in most cases, it will be necessary to transfer the water to the recharge site. This investment item concerns the construction of water transfer infrastructure including the supply pipeline. Depending on distances (up to a few tens of kilometres) and volumes, this investment cost item can be significant in relation to the total investment.

- $\quad$ Cost of recharge water (pre)treatment units $\left(I C_{4}\right)$ : the quality of the recharge water must meet regulation standards for recharge authorization. At a minimum, intermediate settling and filtration basins (primary treatment) could be required to limit the clogging of the recharge structures. Additional treatment (secondary or tertiary treatment) may be required (especially in the case of direct recharge).

- $\quad$ Costs related to land acquisition $\left(I C_{5}\right)$ : the cost of purchasing land for the construction of infiltration basins, which may be significant depending on the location of the recharge site (rural or urbanized environment). It depends on the number and total surface area of the basins, which in turn will depend on the infiltration rate $(i)$ and instantaneous flow rate $(q)$ of the selected site.

- Cost of infiltration basins $\left(I C_{6}\right)$ : in general, this is the main investment item. These costs include the design (civil engineering) and construction of infiltration basins (injection wells in the case of direct recharge), as well as associated equipment.

- $\quad$ Other costs $\left(I C_{7}\right)$ : costs of monitoring equipment (e.g., construction of piezometers), and ancillary works (e.g., protection and development of the recharge site).

\subsubsection{Operating Costs}

Operating costs cover the operating and maintenance costs of the MAR device. These are annual and recurring costs, expressed in $€$ /year. These expenses can also be grouped into seven main items:

- Water purchase cost $\left(O C_{1}\right)$ : if applicable, includes the purchase cost in the case of withdrawal from a water canal or network, as well as charges, levies, or other taxes.

- Maintenance cost of the water intake $\left(\mathrm{OC}_{2}\right)$ : includes the maintenance of the recharge water pumping system in the river.

- $\quad$ Energy cost $\left(\mathrm{OC}_{3}\right)$ : corresponds with the electricity consumption of the equipment and pumping system used to supply the recharge water to the recharge site (if not gravity-fed). It will depend on the flow rate and the price of energy.

- $\quad$ Pre-treatment operational cost $\left(O C_{4}\right)$ : the operational and maintenance costs of the infrastructure for pre-treatment of groundwater (excluding investment). They include, for example, the cost of maintaining and cleaning settling tanks, the cost of chlorination products, etc.

- Cost of maintenance and upkeep of infiltration basins $\left(O C_{5}\right)$ : includes the maintenance of the recharge device (e.g., cleaning of infiltration basins) and its surroundings.

- $\quad$ Monitoring cost $\left(\mathrm{OC}_{6}\right)$ : all the costs related to the control and periodic monitoring of groundwater or recharge water quality (e.g., laboratory analysis cost) or the costs associated with checking the proper functioning of the device (essentially labour costs if an automated control system is not set up).

- $\quad$ Other annual expenses $\left(O C_{7}\right)$ : includes all financial expenses not mentioned above: administrative and personnel management expenses, financial expenses on investment and insurance loans, etc.

\subsubsection{Levelised Cost}

For a MAR scheme, the levelised costs can be defined as the constant level of cost each year to cover all the capital, operating, and maintenance expenses over the life of a MAR project divided by 
the annual volume of recharge (or infiltration). Levelised costs provide an effective means to compare the costs of water from alternative projects [13]. The levelised cost takes into account the duration life $(T)$ of the MAR scheme and the depreciation (or discount) rate $r$, which is the rate at which the value of an asset is reduced each year.

The levelised cost is computed using equations described in Table 2, some of them from the cost Observatory of Rhône Mediterranean Corsica Water Agency (AERMC). The latest provided the levelised cost of pretreatment; therefore, for this cost only, we used assumptions on levelised cost. Finally, the levelised cost is computed using Equation No. 2 (Table 2), considering life duration of the MAR scheme and the discount rate.

Table 2. Summary of costs for a MAR scheme (recharge through infiltration basin option). $\alpha$ and $\beta$ are fractional parameters in order to define specific costs as a fraction of other costs.

\begin{tabular}{|c|c|c|c|c|}
\hline Process & Cost Description & Unit & Cost/Value & Comment \\
\hline \multirow{2}{*}{ Other } & $\begin{array}{l}I C_{1} \text { : engineering } \\
\text { studies }\end{array}$ & $€$ & $I C_{1}=\alpha_{1} \sum_{i=2}^{7} I C_{i}$ & \multirow{2}{*}{$\begin{array}{l}\alpha_{1} \text { ratio of engineering } \\
\text { studies costs } \\
\alpha_{7} \text { ratio of yearly costs }\end{array}$} \\
\hline & $\begin{array}{l}O C_{7} \text { : other yearly } \\
\text { costs }\end{array}$ & $€ /$ year & $O C_{7}=\alpha_{7} \sum_{i=1}^{6} O C_{i}$ & \\
\hline \multirow{3}{*}{ Water abstraction } & $\begin{array}{l}I C_{2}: \text { pump } \\
\text { installation }\end{array}$ & $€$ & $\begin{array}{c}I C_{2}= \\
4520 q+180800\end{array}$ & $q(1 / \mathrm{s})$ \\
\hline & $O C_{1}:$ water cost & \multirow{2}{*}{$€ /$ year } & $O C_{1}=S F+P w Q$ & $\begin{array}{l}\text { SF: subscription fee }(€ / \text { year }) \\
\text { Pw: water price }\left(€ / \mathrm{m}^{3}\right)\end{array}$ \\
\hline & $\begin{array}{l}O C_{2}: \text { pump } \\
\text { maintenance }\end{array}$ & & $O C_{2}=\alpha_{2} I C_{2}$ & $\begin{array}{l}\text { Assumption: portion of } \\
\text { investment costs }\end{array}$ \\
\hline \multirow{2}{*}{ Water transfer } & $I C_{3}:$ pipe building & $€$ & $\begin{array}{c}I C_{3}= \\
D(0.71 d i+19.5)\end{array}$ & $d i:$ pipe diameter $(\mathrm{mm})$ \\
\hline & $O C_{3}:$ lifting energy & $€ /$ year & $O C_{3}=\frac{24 N P e Q H}{367 \eta}$ & $\begin{array}{c}P e: \text { electricity price }\left(€ / \mathrm{m}^{3}\right) \\
\eta: \text { pump efficiency }\end{array}$ \\
\hline \multirow[b]{2}{*}{ Water treatment } & $I C_{4}:$ system building & $€$ & \multirow[b]{2}{*}{$L C_{4}=\beta_{4}\left(€ / \mathrm{m}^{3}\right)$} & $30 \%$ of $\mathrm{LC}_{4}$ \\
\hline & $\begin{array}{l}\mathrm{OC}_{4}: \text { system } \\
\text { maintenance }\end{array}$ & $€ /$ year & & $70 \%$ of $\mathrm{LC}_{4}$ \\
\hline \multirow[b]{3}{*}{ Water infiltration } & $I C_{5}:$ land purchase & $€ / \mathrm{m}^{2}$ & $I C_{5}=L M V S_{S}$ & Land market value $\left(€ / \mathrm{m}^{2}\right)$ \\
\hline & $I C_{6}:$ basin building & $€$ & $\begin{array}{c}I C_{6}= \\
2.28 S_{B} d+61100\end{array}$ & \\
\hline & $\begin{array}{l}\mathrm{OC}_{5}: \text { basin } \\
\text { maintenance }\end{array}$ & $€ /$ year & $\begin{array}{c}O C_{5}= \\
\frac{(P c+P s)}{N_{c}} S_{B} H_{C}+0.1 P m S_{B}\end{array}$ & $\begin{array}{c}\text { Nc: Years between two } \\
\text { dragging processes } \\
\text { Hc: Sand height to be } \\
\text { dragged }(\mathrm{m}) \\
\text { Pc: Sand dragging price } \\
\left(€ / \mathrm{m}^{3}\right) \\
\text { Ps: Sand price }\left(€ / \mathrm{m}^{3}\right) \\
\text { Pm: Neighbours } \\
\text { maintenance price } \\
\left(€ / \mathrm{m}^{2} / \text { year }\right)\end{array}$ \\
\hline \multirow{2}{*}{ Water monitoring } & $\begin{array}{l}I C_{7}: \text { monitoring } \\
\text { equipment }\end{array}$ & $€$ & $I C_{7}=\beta_{7}$ & Assumption \\
\hline & $\begin{array}{l}\text { OC6: yearly } \\
\text { monitoring }\end{array}$ & $€ /$ year & $I C_{6}=\beta_{6}$ & Assumption \\
\hline \multirow{6}{*}{ Total } & $\begin{array}{l}\text { Capital costs IC } \\
\quad(\mathrm{CAPEX})\end{array}$ & $€$ & $I C=\sum_{i=1}^{7} I C_{i}$ & Total of IC \\
\hline & $\begin{array}{l}\text { Operational costs } O C \\
\text { (OPEX) }\end{array}$ & $€ /$ year & $O C=\sum_{i=1}^{7} O C_{i}$ & Total of OC \\
\hline & Operating life $T$ & year & $T$ & \\
\hline & Discount rate $r$ & Decimal & $r$ & \\
\hline & $\begin{array}{l}\text { Capital recovery } \\
\text { factor }(C R F)\end{array}$ & Decimal & $C R F=\frac{r(1+r)^{T}}{(1+r)^{T}-1}$ & No.1 \\
\hline & Levelised cost & $€ / \mathrm{m}^{3}$ & $L C=\frac{C R F C C+O C}{Q}$ & No.2 \\
\hline
\end{tabular}




\subsection{Costs Mapping Method}

In the mapping approach, the study area is gridded according to the DEM resolution $(50 \times 50 \mathrm{~m}$ cell size). In each cell, a land value is determined according to local databases and the infiltration rate is deduced from permeability maps built for numerical modelling studies of the aquifer. For each cell (column $i$, raw $j$ ), shortest distances $D^{n} i, j$ to surface resources (stream or lake) $n$ are computed along with the corresponding elevation difference $Z^{\mathrm{n}}{ }_{i, j}$ between the abstraction cell and the infiltration cell (Figure 2). Using these data, one levelised cost is computed for each cell and $n$ associated surface water resources. Then, for building the cost map, the minimum levelised cost is calculated among the $n$ available resources according to:

$$
L C_{i, j}=\min \left(L C_{i, j}^{1} L C_{i, j}^{2} \ldots L C_{i, j}^{n}\right)
$$

The minimum cost is therefore considered for each cell of the analysis domain.

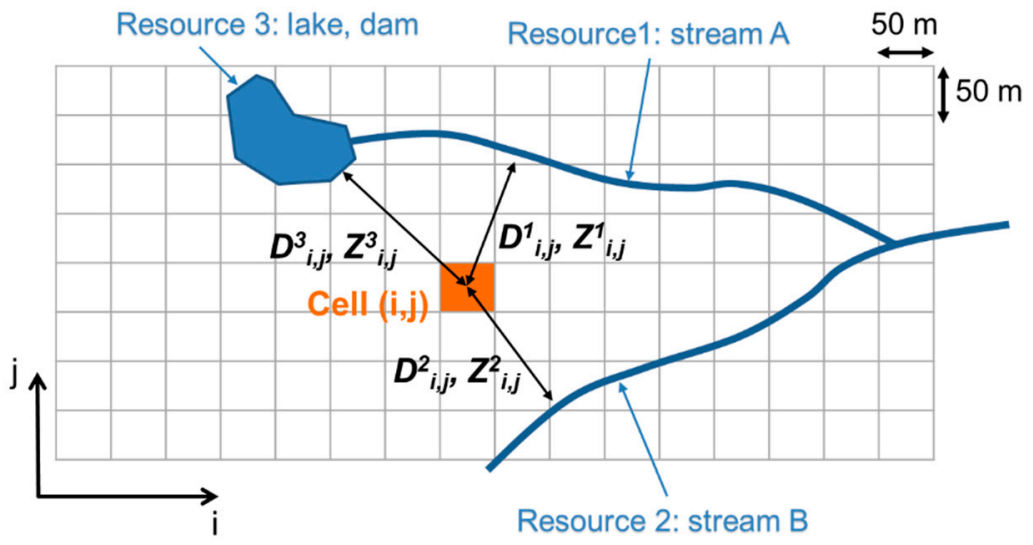

Figure 2. Cells gridding of the study area (example for a case with $n=3$ available water resources: two streams and one lake). $D^{\mathrm{n}}{ }_{i, j}$ and $H^{\mathrm{n}}{ }_{i, j}$ are, respectively, minimum distance and elevation difference between the cell $(i, j)$ and resource $n$.

\section{Reference Case Study}

\subsection{Case Study Description}

The reference case used was the Vistrenque and Costières Plain case study (VCP). This aquifer is located in Southern France between the Gardon River to the east and the Vidourle River to the west (Figure 3). The VCP area consists of a plain (Vistrenque) and a plateau at very low altitude (Costières) bordered to the north by the Nîmes garrigues and to the south by the Rhône plain and the Petite Camargue. Several types of unconsolidated rocks, among which alluviums largely dominate, constitute the aquifer. The VCP aquifer is unconfined on $84 \%$ of its surface area and confined on the rest.

Up until now, the aquifer is considered as being in a fragile hydraulic equilibrium, but the expected climate change impact on natural recharge and the increase of water abstraction induced by population concentration should lead to a potential water table decline, as already observed in the past during dry periods. Apart from water saving measures, MAR through infiltration basin using available surface water constitutes a possible alternative solution.

There are several surface water resources in the study area:

- The Vidourle River, to the west, is characterized by a very low baseflow and frequent flash floods. Water could be abstracted only during medium to high flow periods (excluding baseflow period).

- The Vistre River crosses the aquifer from northeast to southwest. Due to bad water quality, this river does not constitute a possible surface water resource for MAR. 
- $\quad$ The Bas-Rhône and Languedoc regional water company (BRL) canal network conveys water from the Rhône River mainly for irrigation purposes. Its very well connected network of canals constitutes an efficient way of bringing surface water into the plains.

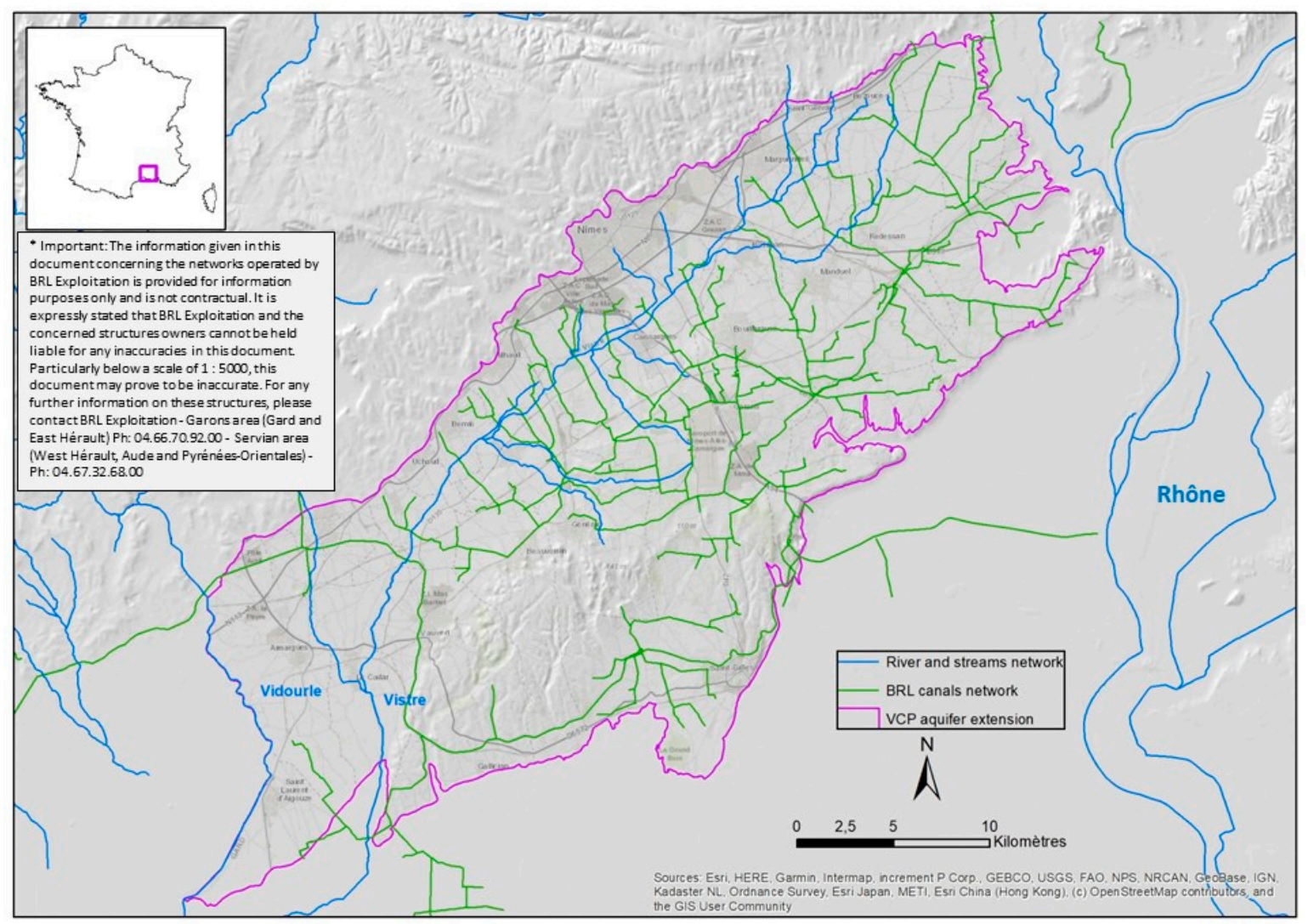

Figure 3. Map of the Vistrenque and Costières Plain (VCP) case study. Available surface water for MAR purposes is identified (in blue: rivers and streams; in green: Bas-Rhône and Languedoc regional water company (BRL) canal network).

\subsection{MAR Design and Characteristics}

The characteristics of the MAR scheme project on the VCP case study are summarized at Table 3. In that case study, the recharge rate objective was fixed at $1 \mathrm{Mm}^{3} /$ year for 8 months $(N=243$ days/year $)$ because surface water (canals or rivers) was not available during 4 months/year in low stages. For the reference case, we assumed a distance and an elevation difference between the surface resource and the infiltration basin, respectively, of $1000 \mathrm{~m}$ and $-10 \mathrm{~m}$. We considered that the solution of free water (from the river) was preferable to the canal water which is costly. We assumed that a primary pretreatment was necessary to remove the silt and fine material present in the river water. Its levelised cost was $L C_{4}=0.10 € / \mathrm{m}^{3}$. Other parameters (regarding basin dragging and maintenance) are listed in Table 3 . 
Table 3. Main characteristics of the MAR project on the VCP case study.

\begin{tabular}{|c|c|c|}
\hline Process & Parameter & Value \\
\hline \multirow{2}{*}{ Other } & Engineering studies cost rate & $\alpha_{1}=0.10$ \\
\hline & Other yearly costs rate & $\alpha_{7}=0.10$ \\
\hline \multirow{4}{*}{ Water abstraction } & Recharge rate & $Q=10^{6} \mathrm{~m}^{3} /$ year \\
\hline & Recharge duration per year & $N=243$ days/year \\
\hline & Flow rate & $\begin{array}{c}q=4115 \mathrm{~m}^{3} / \text { day } \\
q=171.5 \mathrm{~m}^{3} / \mathrm{h}\end{array}$ \\
\hline & Pump maintenance cost rate & $\alpha_{2}=0.10$ \\
\hline \multirow{5}{*}{ Water transfer } & Distance & $D=1000 \mathrm{~m}$ \\
\hline & Altitude difference & $Z=-10 m$ \\
\hline & Head losses & $H=21 \mathrm{~m}$ \\
\hline & Pipe diameter & $\mathrm{di}=0.179 \mathrm{~m}$ \\
\hline & Pump efficiency & $\eta=0.80$ \\
\hline Water treatment & Levelised cost & $\beta_{4}=0.10 € / \mathrm{m}^{3}$ \\
\hline \multirow{8}{*}{ Water infiltration } & Soil infiltration rate & $i=1 \mathrm{~m} /$ day \\
\hline & Infiltration basin surface area & $S_{B}=4115 \mathrm{~m}^{2}$ \\
\hline & System surface area & $S_{S}=4527 \mathrm{~m}^{2}$ \\
\hline & Land market value & $L M V=1 € / \mathrm{m}^{2}$ \\
\hline & Basin depth & $d=2.5 \mathrm{~m}$ \\
\hline & Duration between two dragging & $N c=5$ years \\
\hline & Sand height to be dragged & $H c=0.30 \mathrm{~m}$ \\
\hline & Sand dragging and sand prices & $\begin{array}{c}P_{C}=3 € / \mathrm{m}^{3} \\
P_{S}=10 € / \mathrm{m}^{3}\end{array}$ \\
\hline \multirow{2}{*}{ Water monitoring } & Investment cost & $\beta_{7}=20,000 €$ \\
\hline & Operating cost & $\beta_{6}=0.10$ \\
\hline \multirow{2}{*}{ Financial data } & MAR scheme life duration & $T=30$ years \\
\hline & Local discount rate & $r=0.04$ \\
\hline
\end{tabular}

\section{Results}

\subsection{Reference Case}

The total investment cost obtained for the VCP case study was $€ 1.7$ million. The predominant cost items were the cost of implementing the pretreatment system $\left(I C_{4}\right)$, as well as the cost $\left(I C_{2}\right)$ of installing the water abstraction system (here, the reference example considered a river intake), corresponding to $53 \%$ and $23 \%$ of the total investment cost, respectively (Figure 4 ). The costs related to land purchase $\left(I C_{5}\right)$ and monitoring costs $\left(I C_{7}\right)$ represented a negligible part of the total investment costs. The investment cost of transferring water $\left(I C_{3}\right)$ was low compared to $I C_{4}$ and $I C_{2}$. In cases where the distance $D$ (1000 $\mathrm{m}$ in the reference example) between the surface water resource and the recharge area is higher, this cost item can take a significant part of the total investment cost.

The graph below summarizes the operating costs for the same reference case (Figure 4). The cleaning was fixed every $N c=5$ years, on a removal and replacement of $H c=30 \mathrm{~cm}$ of gravel pack. The total operating cost obtained was nearly $130,000 € /$ year. The predominant cost item was the cost related to the pre-treatment of water $\left(\mathrm{OC}_{4}\right)$, corresponding to $54 \%$ of the total operating cost (Figure 4). The water transfer cost (energy, $O C_{3}$ ) was reasonably high in our reference example because 
an average altitude difference $(-10 \mathrm{~m})$ was chosen. If the water supply to the device was gravitational, $O C_{3}$ would have been negligible. In the case where water was drawn from canals or water networks, the water purchasing cost $O C_{1}$ became one of the main cost items. Although it was generally perceived as high by operators, the cost of maintaining the basin and its surroundings $\left(O C_{5}\right)$ was found to be low compared to other cost items, such as $\mathrm{OC}_{4}$.

In this reference case, both investment and operating costs were dominated by pretreatment cost (i.e., in this case an assumption of a pretreatment levelised cost of $0.10 € / \mathrm{m}^{3}$ ).

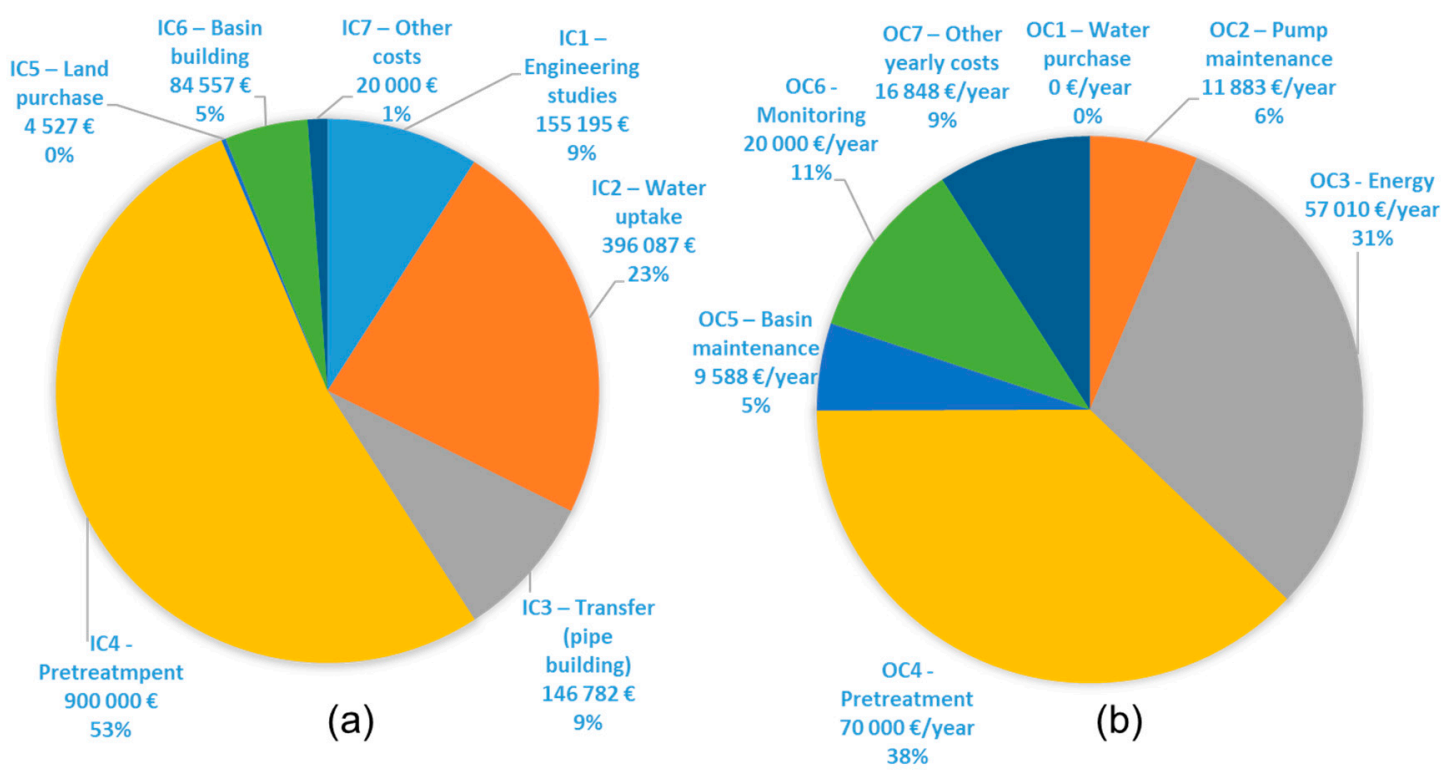

Figure 4. Partition of the various cost items for the reference case: (a) investment costs, IC (in $€$ ) and (b) operating costs, OC (in $€ /$ year).

\subsection{Levelised Costs Mapping}

The levelised cost map was obtained for the VCP case study applying Equation No. 2 (Table 2) using parameters from Table 3 and spatial variables distributed on the VCP maps (Figure 5a-d). The map of levelised cost is presented below (Figure 5e). The black areas correspond to the sectors excluded from the cost analysis (mask created from the unfavourable sectors from land use analysis), in order to isolate urbanized, artificialized areas, where it would be impractical and less interesting to install an MAR device (in addition to the difficulty of estimating land costs on these sectors).

The levelised cost LC ranged from $0.13 € / \mathrm{m}^{3}$ (along the Vidourle) to nearly $0.55 € / \mathrm{m}^{3}$ (on the contours of the entity; Figure 5). The average LC (average over the whole entity) was $0.29 € / \mathrm{m}^{3}$. The most prominent criteria were:

- $\quad$ The purchase of water $\left(O C_{1}\right)$ from BRL (high costs near the canals and raw water networks of the Gard);

- $\quad$ The levelised cost of water pre-treatment $L C_{4}$ (considered at $0.10 € / \mathrm{m}^{3}$ for BRL resources and $0.05 € / \mathrm{m}^{3}$ for Vidourle river);

- $\quad$ Distance to resource $D$ (price decreased from surface water resources, linked to the increase in the cost of water transfer);

- The soil infiltration rate $i$ (less infiltrating zones in orange, made up of Astian sands of the Costières, less permeable formation than the others, near Beauvoisin, Générac, Saint-Gilles, and Bellegarde);

- $\quad$ The difference in altitude $Z$ (visible in particular in a flatter area in the commune of Cailar). 

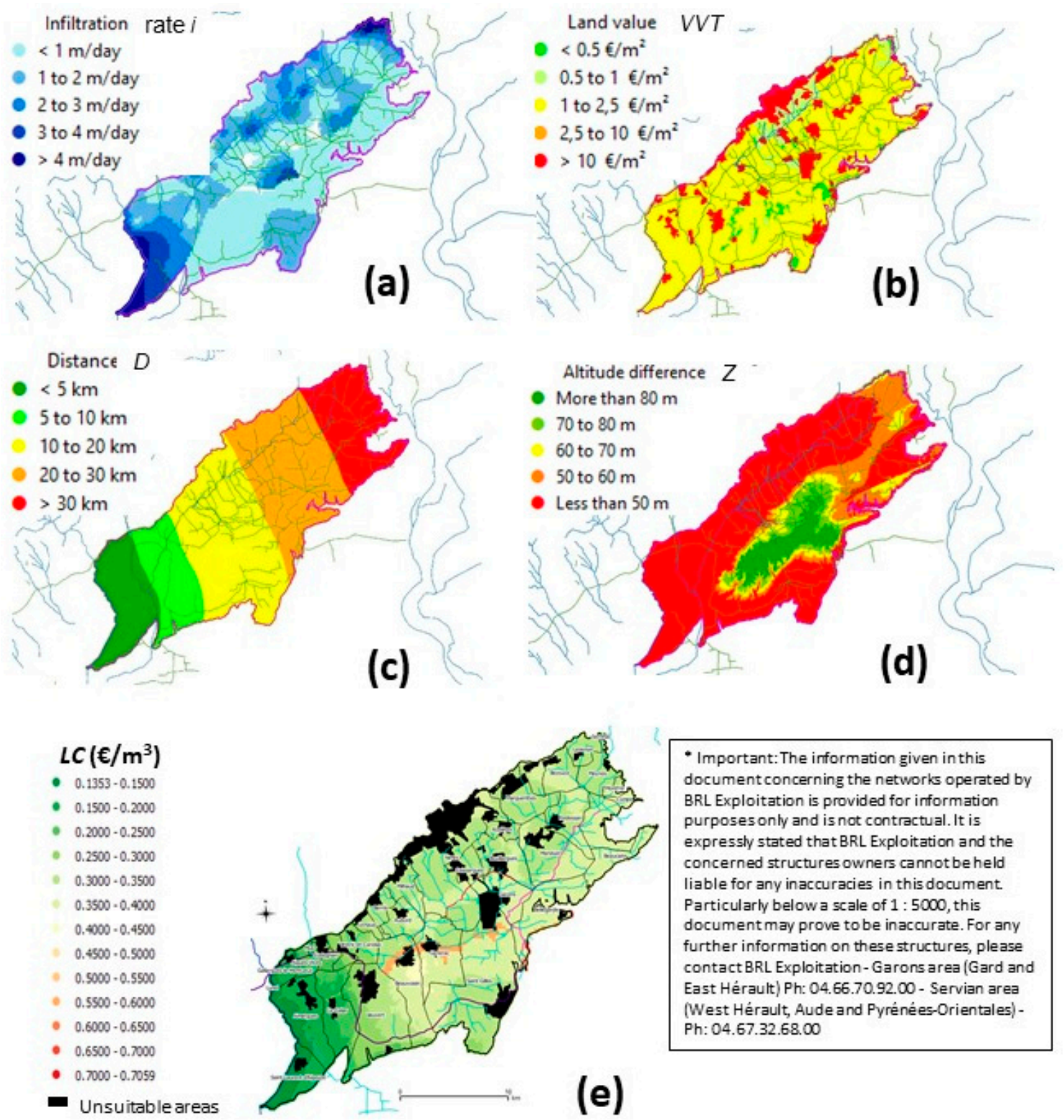

- Important: The information given in this document concerning the networks operated by BRL Exploitation is provided for information purposes only and is not contractual. It is expressly stated that BRL Exploitation and the concerned structures owners cannot be held liable for any inaccuracies in this document. Particularly below a scale of $1: 5000$, this document may prove to be inaccurate. For any further information on these structures, please contact BRL Exploitation-Garons area (Gard and East Hérault) Ph: 04.66.70.92.00 - Servian area (West Hérault, Aude and Pyrénées-Orientales) Ph: 04.67.32.68.00

Figure 5. VCP case study: (a) map of soil infiltration rates $i$ (m/day), (b) land market value $L M V\left(€ / \mathrm{m}^{2}\right)$, (c) distance to one river $D$ (Vidourle in this case), (d) elevation difference $Z$ with closest river/stream, (e) minimum levelised cost LC map (in black: areas identified as unfavourable to infiltration basins due to land use constraints, most of the time corresponding to urban areas).

\section{Discussion}

\subsection{Sensitivity Analysis}

A systematic sensitivity analysis was performed to determine the effect of various parameters on the levelised cost of the MAR scheme. Sensitivity is defined as the rate of variation in one factor with respect to a variation in another factor. The normalized sensitivity is used to compare parameters and is defined as [14]:

$$
S_{i, t}=\frac{\partial O}{\partial P_{i} / P_{i}}
$$

where $S_{i, t}$ is the normalized sensitivity of $i$ th input parameter at time $t, \mathrm{O}$ is the output function of the system (i.e., the levelised cost in this case), and $P_{i}$ is the ith input parameter of the system (in our case: 
$\mathrm{T}, \mathrm{Q}, \mathrm{r}, \mathrm{D}$, etc.). The partial derivative of this equation can be approximated by a forward differencing formula as [15]:

$$
\frac{\partial O}{\partial P_{i}}=\frac{O\left(P_{i}+\Delta P_{i}\right)-O\left(P_{i}\right)}{\Delta P_{i}}
$$

The latest equation measures the influence that the fractional variation in a parameter, or its relative error, has on the output [15].

It must be specified that it is not a GIS-MCDA sensitivity analysis but a sensitivity analysis of the levelised cost of MAR scheme in the VCP case that has been computed for all the input parameters. They can be classified into three groups: (i) group 1 contains the highly sensitive parameters: life duration $(T)$, recharge volume $(Q)$, distance $(D)$, and elevation difference $(Z)$ between water uptake and infiltration basin, and water purchase and pretreatment costs; (ii) group 2 contains moderately sensitive parameters: yearly availability of water $(N)$, soil infiltration rate $(i)$, and discount rate $(r)$; (iii) group 3 contains the lowly sensitive parameters: land market value $(L M V)$, infiltration basin depth $(p)$, duration between basin desilting $(\mathrm{Nc})$, and thickness $(\mathrm{Hc})$ of sands to scrab. The results for four of the most sensitive parameters are illustrated at Figure 6 with the following range of variation being explored: system life duration between 5 and 35 years, distance $D$ between 0 and $5000 \mathrm{~m}$, annual recharge volume between 0.01 and $5 \mathrm{Mm}^{3} /$ year, and water treatment cost between 0 and $0.30 € / \mathrm{m}^{3}$. The cost sensitivity is positively linearly dependent on distance between abstraction and infiltration locations, and on water treatment cost, which tend to dominate the levelised cost beyond median values. The levelised cost appears to be highly dependent on annual recharge volume and life duration of the system, especially at low values of these parameters. This means, for example, that the levelised cost can be highly reduced by increasing the annual recharge volume up to $1 \mathrm{Mm}^{3} /$ year $(\approx 0.2$ of parameter range, $x$ axis of graph at Figure 6). Regarding the system life duration, the minimum life duration should be above 20 years ( $>0.5$ of parameter range).

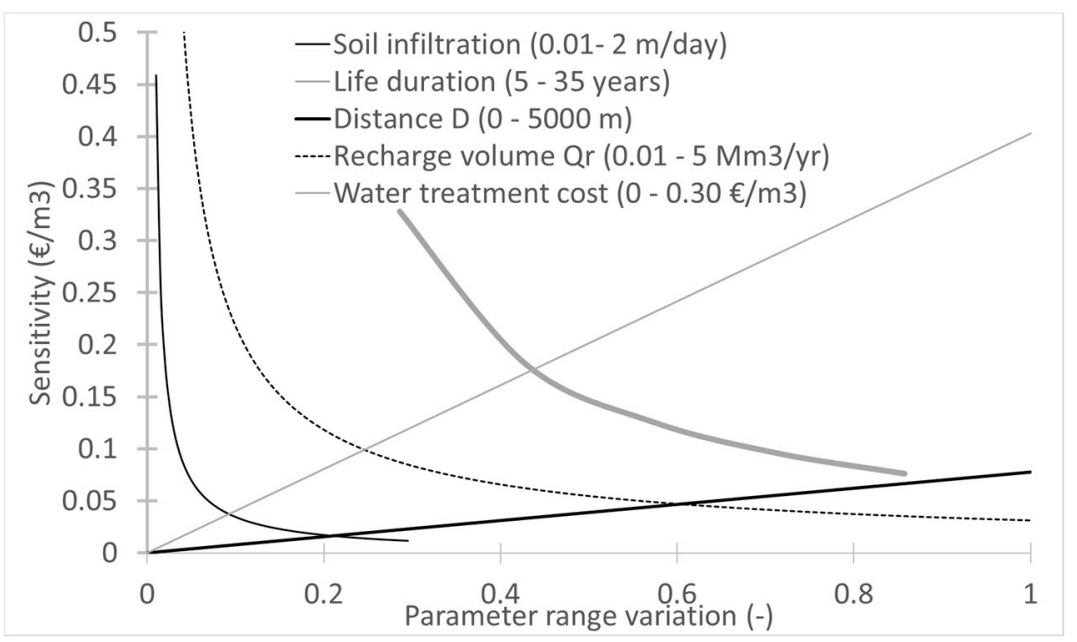

Figure 6. Levelised cost sensitivity analysis to water treatment cost, recharge water volume, MAR system life duration, and distance between the abstraction and recharge locations.

\subsection{Approach Limitations and Outlines}

This methodology relies on several assumptions regarding various costs and technical characteristics of the MAR scheme, which result in uncertainties in the final computed levelised cost screening. Therefore, the method should not be used as an accurate tool in a prefeasibility analysis but as a tool to compare several options concerning, for example, (i) the location of the MAR scheme, (ii) the water resource which will be used, or (iii) the required pretreatment processes. The tool can also be improved during the pre-project analysis as new data and information are collected in engineering studies. 
The various criteria considered in the cost function are derived from various sources; economic and financial feedback; and, in some cases, are based exclusively on expert opinion, in the absence of information from the literature. It is therefore important to consider that the costs obtained at the end of this analysis are orders of magnitude, based on a certain number of assumptions. For this reason, the method should be used in a relative way, with the objective to site projects at locations with relatively low costs.

The cost assessment carried out in this study is similar to a cost-efficiency analysis (CEA), considering that all the volumes of water brought to the infiltration basin are recharged and stored in groundwater. No consideration was given to the capacity of the aquifer to store infiltrated water, nor the ability to retain it so that it can be recovered for high-valued uses. Part of the recharged water may enhance the discharge of groundwater to watercourses or other aquifers. Additional hydrogeological investigations are needed in order to evaluate the contribution of recharged water to intended economic and environmental benefits. The analysis carried out did not include the assessment of such benefits of MAR projects. This may require aquifer characterization and hydrodynamic modeling of the site.

\section{Conclusions}

This methodology was provided in order to approximate the levelised cost of an MAR scheme using an infiltration basin. Uncertainty in several input parameters and the lack of economic and financial feedback on MAR system costs introduce uncertainty into the calculated levelised cost.

The developed tool should be used as a way to identify the sensitivity of the cost for several input parameters, as well as guiding the sitting of the MAR device in a relative way. It should help in making decisions on the design of the MAR system. The method is general and can be applied in other contexts and other countries where information on MAR costs is available thanks to economic feedback.

Finally, this information on economical feasibility should be followed by more classical suitability analysis such as those relying on soil characteristics, aquifer storage capacity, and land use in order to properly site the MAR scheme. The levelised cost provides an effective means to compare the costs of MAR with alternative water projects.

Author Contributions: J.-C.M. and J.-D.R. had the original idea; M.B. and J.-C.M. conceived the methodology; F.M. and M.B. developed the tool; J.-F.D. developed the GIS application; F.M. applied the methods/tools and analysed the data; Y.C. contributed to materials and analysis tools; J.-C.M. wrote the paper. All authors have read and agreed to the published version of the manuscript.

Funding: This research was funded by Bureau de Recherches Géologiques et Minières (BRGM, French Geological Survey) and Agence de l'Eau Rhône-Méditerranée-Corse (Rhone Mediterranean Corsica Water Agency).

Acknowledgments: This study results from a scientific collaboration between Bureau de Recherches Géologiques et Minières (French Geological Survey) and Agence de l'Eau Rhône-Méditerranée-Corse (Rhone Mediterranean Corsica Water Agency).

Conflicts of Interest: The authors declare no conflict of interest.

\section{Abbreviations}

The following abbreviations are used in this manuscript:

$\begin{array}{ll}\text { MAR } & \text { managed aquifer recharge } \\ \text { MCDA } & \text { multi-criteria decision analysis } \\ \text { IC } & \text { investment cost } \\ \text { OC } & \text { operating cost } \\ \text { DEM } & \text { digital elevation model } \\ \text { GIS } & \text { geographic information system } \\ \text { VCP } & \text { Vistrenque and Costières Plain case study } \\ \text { AERMC } & \text { Rhone Mediterranean Corsica Water Agency } \\ \text { BRL } & \text { Bas-Rhône and Languedoc regional water company }\end{array}$




\section{References}

1. Wada, Y.; Van Beek, L.P.H.; Van Kempen, C.M.; Reckman, J.W.T.M.; Vasak, S.; Bierkens, M.F.P. Global depletion of groundwater resources. Geophys. Res. Lett. 2010, 37. [CrossRef]

2. Aeschbach-Hertig, W.; Gleeson, T. Regional strategies for the accelerating global problem of groundwater depletion. Nat. Geosci. 2012, 5, 853-861. [CrossRef]

3. Dillon, P.; Stuyfzand, P.; Grischek, T.; Lluria, M.; Pyne, R.D.G.; Jain, R.C.; Bear, J.; Schwarz, J.; Wang, W.; Fernandez, E.; et al. Sixty years of global progress in managed aquifer recharge. Hydrogeol. J. 2019, 27, 1-30. [CrossRef]

4. David, R.; Pyne, G. Groundwater Recharge and Wells; Routledge: Boca Raton, FL, USA, 2017.

5. Stefan, C.; Ansems, N. Web-based global inventory of managed aquifer recharge applications. Sustain. Water Resour. Manag. 2018, 4, 153-162. [CrossRef]

6. Rahman, M.A.; Rusteberg, B.; Gogu, R.C.; Lobo Ferreira, J.P.; Sauter, M. A new spatial multi-criteria decision support tool for site selection for implementation of managed aquifer recharge. J. Environ. Manag. 2012, 99, 61-75. [CrossRef] [PubMed]

7. Sallwey, J.; Bonilla Valverde, J.P.; Vásquez López, F.; Junghanns, R.; Stefan, C. Suitability maps for managed aquifer recharge: A review of multi-criteria decision analysis studies. Environ. Rev. 2019, 27, 138-150. [CrossRef]

8. Sallwey, J.; Schlick, R.; Bonilla Valverde, J.P.; Junghanns, R.; Vásquez López, F.; Stefan, C. Suitability Mapping for Managed Aquifer Recharge: Development of Web-Tools. Water 2019, 11, 2254. [CrossRef]

9. Maliva, R.G. Economics of managed aquifer recharge. Water 2014, 6, 1257-1279. [CrossRef]

10. Ross, A.; Hasnain, S. Factors affecting the cost of managed aquifer recharge (MAR) schemes. Sustain. Water Resour. Manag. 2018, 4, 179-190. [CrossRef]

11. Escalante, E.F.; Gil, R.C.; Fraile, M.Á.S.M.; Serrano, F.S. Economic assessment of opportunities for Managed Aquifer recharge techniques in Spain using an advanced geographic information system (GIS). Water 2014, 6, 2021-2040. [CrossRef]

12. Dillon, P.; Arshad, M. Managed aquifer recharge in integrated water resource management. In Integrated Groundwater Management: Concepts, Approaches and Challenges; Springer International Publishing: Berlin/Heidelberg, Germany, 2016; pp. 435-452, ISBN 9783319235769.

13. Dillon, P.; Pavelic, P.; Page, D.; Beringen, H.; Ward, J. Managed Aquifer Recharge: An Introduction. 2009. Available online: http://hdl.handle.net/102.100.100/113803?index=1 (accessed on 20 February 2020).

14. Kabala, Z.J. Sensitiviby analysis of a pumping test on a well with wellbore storage and skin. Adv. Water Resour. 2001, 24, 483-504. [CrossRef]

15. Huang, Y.C.; Yeh, H. Der The use of sensitivity analysis in on-line aquifer parameter estimation. J. Hydrol. 2007, 335, 406-418. [CrossRef]

(C) 2020 by the authors. Licensee MDPI, Basel, Switzerland. This article is an open access article distributed under the terms and conditions of the Creative Commons Attribution (CC BY) license (http://creativecommons.org/licenses/by/4.0/). 